\title{
THE CHALLENGES OF EXTENDED \\ CONFISCATION. DIRECTIVE 2014/42/EU AND TRANSPOSING DIFFICULTIES IN ROMANIA
}

\author{
Adrian Stan, LLM, PhD Candidate \\ West University, Law Faculty \\ Timișoara, Romania \\ av.stanadrian@gmail.com
}

\begin{abstract}
A relatively new institution in Romanian criminal law, adopted in 2012 as a result of the imperative of transposing the international and European legal instruments of the last decades, the institution of "extended confiscation" has hardly found its place in the Romanian legal system, and it can be said that it conflicts with some traditional constitutional principles from which it is not possible to derogate. Thus, on the one hand, Romania has to respect its international commitments and, on the other hand, it must avoid violating some of the rights that have been hard-earned by Romanian young democratic constitutionalism.
\end{abstract}

That is why the extended confiscation, this "necessary evil", or compromise of modern criminal law, has already begun and we are sure it will generate in the future a lot of theoretical discussions and controversies, but it also encounters a certain retention of the practice, specific to all the innovative criminal law institutions.

In the Romanian criminal system, extended confiscation is situated among the "safety measures", near the "hospitalization based on mental illness" or "prohibition of practicing a profession". As said in the legal text, the purpose for these measures, developed in the early $20^{\text {th }}$ century by the Italian Positivist school, is the "social defence”. More precisely, it is about removing an existing "state of danger" and preventing the commission of future crimes. However, the extended confiscation is different. The goods so-called "proceeds of crime" do not have to be obtained directly from an offence for which the accused is convicted, but from a general unlawful conduct similar to that crime.

I will observe, therefore, in the first chapter of my paper, the international context of fight against organized crime and its proceeds. After that, I will present the actual situation of the extended confiscation in Romania and its place between the criminal measures. In the next chapters I will insist on the concept of dangerousness and also observe the very little difference between the extended confiscation and a criminal punishment, because here we do not talk about the danger of some goods (as in the "classic" or the "common" confiscation, like drugs, guns), but about the danger of the detainer of those things.

In the last chapter I will present the recent challenges in transposing the Directive 2014/42/ $E U$, especially regarding the standard of proof (beyond any doubt) and the recent unconstitutional decision in this case.

Keywords: "crime do not pay", special confiscation, extended confiscation, social defence, state of danger, punishment. 


\section{PRELIMINARY REMARKS}

It can be said that the institution of extended confiscation is new in the Romanian criminal law, being adopted only as a result of the imperative of transposing the numerous legal instruments of international and community law in the last decades. Sometimes called inexactly "non-conviction based confiscation" (this is because the conviction, which is requested, refers to other proceeds), it has hardly found its place in Romanian legal system, and one can say that it is in contradiction with some constitutional principles, from which it is difficult to derogate.

This "necessary evil" of modern criminal law has, and will continue to generate a series of theoretical discussions and controversies, also encountering a certain retention of the practice specific to all innovative institutions. Of course, we will try, within the limits of our study, given the fact that the topic is particularly generous, to point out some aspects of the issue of positioning the extended confiscation at the limit between the two criminal law sanctions, punishments and security measures. We will start by placing the fight against profit criminality in an international and European context, then we will take a look at the discussions in the thirties of the last century about the legal nature of confiscation, and then we will identify elements that bring the extended confiscation closer to the punishments. In the end, we have made some critical remarks of the proposals to amend the Romanian Criminal Code in the matter of standard of proof regarding the measure under analysis.

The study does not refer to civil orders of confiscation ("civil forfeiture" in the US $)^{1}$, which can be found in numerous common-law systems, existing also in Romanian system and based on a previous civil control of the wealth of public officials. We will refer only to the special situation of extended confiscation related to criminal offences and ordered in criminal procedures.

\section{THE INTERNATIONAL CONTEXT OF FIGHT AGAINST THE PROCEEDS OF CRIME}

Confiscation of criminal assets has become a necessity in the fight against organized crime in the late eighties of the twentieth century, in the context of an explosion of profit-driven crime. Traditional "repressive" criminal law is no longer

In a non-conviction based forfeiture proceeding in the US, there is no requirement of a criminal conviction or even of a criminal investigation. The government brings the action against the property as the defendant in rem, and any person seeking to oppose the forfeiture must intervine to do so. Cassella S., Civil Asset Recovery, in: Rui, J.P., Sieber, U. (eds), Non-conviction based confiscation in Europe. Possibilities and limitations on rules enabling confiscation without a criminal conviction, Duncker and Humblot, Berlin, 2015, p. 17 
sufficient to deal with the new threats posed by the global risks and information society. Money is the glue that holds criminal organised enterprises together: they have to recycle the money, to buy more drugs, to finance acts of terrorism, to pay bribes to officials ${ }^{2}$.

The magnitude of criminality also called "entrepreneurial" has caused the interest in seizure and recovering illicitly-acquired wealth to become one of the main objectives of global criminal policy. Criminal organizations have the ultimate goal of economic profit and prosperity due to illegal financial flows ${ }^{3}$. The proceeds of the crime had become, on the one hand, a constant part of the purpose of the criminal activity and, on the other hand, a central objective of the authorities. International law as a system has become aware of the danger and started to react ${ }^{4}$.

The first signs that the member states of the international organizations intend to fight to recover the proceeds obtained as a result of the illicit activities were, however, older, as there were discussions in the years between the two world wars ${ }^{5}$. In this sense ${ }^{6}$ it is worth mentioning the works of the 1926 International Congress in Brussels, the International Conference on the Unification of Criminal Law in Rome, 1928, the Congress of the International Criminal and Penitentiary Commission in Prague, 1930. Some of the discussions were at the level of principle and, even though they took place under the League of Nations, an organization that proved ineffective in the context of fragile collective security ${ }^{7}$, they had the role of inspiring the criminal codes that many European states have adopted in the thirties of the last century.

Comparative Law scholars ${ }^{8}$ refer to traditional forms of confiscation and to modern forms of the institution. Among the forms of tradition are the general confiscation (corresponding to the complementary punishment of confiscation of wealth in the old Romanian communist system of law, almost completely abandoned by modern laws) and the special confiscation (which is regulated in the current

$2 \quad$ Idid., p. 15

3 Corvi, P., La confisca nei reati di criminalita organizzata, in Sequestro e confisca, a cura di Mariangela Montagna, G.Giappichelli Editore-Torino, 2017, p. 432.

4 Sigursteinsson, B. H. The Globalization of Crime Control: The Use of Non-criminal Justice Responses for Countering Organized Crime, p. 2, at: [https://www.mobt3ath.com/uplode/book/book-48543.pdf] Accessed 15.03.2019

5 In the US, forfeiture laws are older, since the late 1700s, when the pirate ships and cargo could be seized

6 Ionescu-Dolj, I, în G. Constantin Rătescu, Asnavorian, H., Pop, T., Dongoroz, V., Codul penal "Regele Carol II" adnotat, vol. I-III, Editura Socec \& Co S.A.R., Bucureşti, 1937, p. 169

7 Constantin, V., Drept internațional public, Ed. Universităţii de Vest, Timişoara, 2004, p. 32

$8 \quad$ Pradel, J., Droit pénal comparé, 4 édition, Dalloz, Paris, 2016, pp. 598-599 
Criminal Code in article 112). Special confiscation refers, lato sensu, to things produced, acquired, obtained or used to commit the criminal offence (products and proceeds of crime). Modern forms of confiscation refer to equivalent confiscation when the confiscation of the above-mentioned goods is not materially possible.

Extended confiscation is certainly something more than the aforementioned classic forms of the measure. This is because on the one hand it concerns different goods than the object of ordinary confiscation, and on the other hand the accused has to be convicted ${ }^{9}$ for committing a crime (with all its elements), and not just for committing an act provided by criminal law.

Then, this exceptional security measure imposes a certain degree of conviction of the judge regarding the criminal origin of the goods. The conviction has to be based on a "unlawful conduct", even in the absence of bringing to trial the alleged facts which have generated them. So, the conviction of the judge is formed on the basis of a presumption of perpetuating a criminal behaviour of the accused. This is raising a series of questions about the nature of the measure, the burden of proof and the presumption of innocence of the person subject of it.

In order to accelerate the fight for the confiscation of proceeds of crime and of illicit property, the United Nations took the first step in 1988 in Vienna, adopting the Convention against Illicit Traffic in Narcotic Drugs and Psychotropic Substances. Subsequently, the Council of Europe Convention on laundering, detection, seizure and confiscation of the proceeds of crime (Strasbourg, 1990), the International Convention for the Suppression of the Financing of Terrorism (UN), New York, 1999, the UN Convention against Transnational Organized Crime (2000), the UN Convention against Corruption (New York, 2003), the Council of Europe Convention on laundering, detection, seizure of the proceeds of crime and terrorist Financing (adopted in Warsaw on 16 May 2005).

Financial crime is frequently committed in business relations. Considering the efforts of the EU to tackle various forms of financial crime, efforts which have definitely intensified since the 2008 financial crisis, it would not come as a surprise that the EU had also sought to strengthen its grip on national law in order to combat corporate (financial) crime. $^{10}$

9 Except for other ways to individualize the punishment provided by the Romanian new criminal code, such as waiving the punishment or postponing the punishment

10 Franssen, V., The EU's Fight Against Corporate Financial Crime: State of Affairs and Future Potential, German Law Journal, no. 5, 2018, at : [https://static1.squarespace.com/static/56330ad3e4b0733dcc0c8495/t/5bb17002f4e1fcbd8b2b47c2/1538355202984/Vol_19_No_05_Franssen.pdf

Accessed 19.03.2019 
Thus, initially in connection with organized crime and especially with drug trafficking, over the years, extended criminal confiscation has witnessed a progressive amplification. It is now covering a number of other crimes and became an incisive tool in the "attack" on illicit property. For example, in Italy there is "confisca penale allargata", in Spain "decomiso ampliado" in Germany and Austria "Erweiterter Verfall" in the United Kingdom "confiscation order"11.

\section{SHORT BRIEF ON IMPLEMENTATION OF EXTENDED CONFISCATION IN ROMANIAN CRIMINAL LAW}

Taking on with delay the obligations undertaken following the accession to the European Union in 2007, Romania only amended the Criminal Code to introduce the new form of confiscation by Law no. 63/2012 $2^{12}$. The exposure of reasons ${ }^{13}$ of the law is relevant. The reason for the drafting the act was the transposing of art. 3 of the Framework Decision no. 2005/212/JAI on the confiscation of crime-related products, instrumentalities and other property ${ }^{14}$.

Thus, it appears that although at that time (2012) Romania benefited from a coherent and comprehensive legislative framework, developed in accordance with the international standards in the field of confiscation of crime proceeds, this framework had certain gaps in relation to the European requirements in this field. More specifically, at the level of internal legislation, the Framework Decision was not fully transposed. The national legislation was lacking the transposition of Art. 3 of the Community act on extended confiscation. In all cases, it is also stated that it allows the confiscation of goods obtained from criminal activities that are not directly related to the offence for which the person is convicted, namely, the direct connection between the crime leading to the conviction and the goods that are confiscated is not proven.

The legislator, arguing the necessity of the new measure, also notes that not in all cases is it possible to prove the direct connection between the crime for which the person has been convicted and certain assets, even if the illicit origin of the goods is obvious.

11 Furcinitti, G., Frustagli, D., Il sequestro e la confisca dei patrimoni illeciti nell'Unione Europea, Wolters Kluwer, CEDAM, 2016, pp. 10-11

12 Published in the Official Journal no. 258, 19 April 2012

13 [http://www.cdep.ro/proiecte/2011/700/80/5/em785.pdf] Accessed 21.02.2019

14 Adopted at Brussels on 24 February 2005 and published in the Special Edition of the Official Journal of the European Union no. 0, 1 January 2007 
Introduced in the old Criminal Code (adopted in 1968) in art. 118, after the entry into force of the current Criminal Code in 2014, the provisions were assumed in art. $112^{1}$. We will not insist on all the elements of the "safety measure" as they have been extensively dealt with in the literature ${ }^{15}$; however, we will analyse its controversial legal nature, which is rather closer, in our opinion, to the idea of punishment than to the classical security measures.

Thus, the Romanian legislator in 2012 opted in the regulation of the special measure for the possibility of ordering the extended confiscation of other goods than those that could be subjected to the classical measure of special confiscation (we are talking, lato sensu, about the proceeds of the crime). As will be shown below, these proceeds, object to extended confiscation, are not directly related to the offence for which the defendant is tried and convicted, but they must be obtained only from similar activities.

The Romanian law enumerates a series of offences presumed to generate illicit proceeds, where the extended confiscation of property of the convicted may be involved (e.g. drug trafficking, money laundering, human trafficking, corruption, tax evasion, border-related offences etc.). In addition, the law also sets a minimum four-year limit punishment for these offences. It could be said that duplication would be without sense, because, as a rule, these offences are serious. However, when talking about offences against property, by reference to the limit of punishment, acts of simple theft, without aggravating circumstances (where the maximum sentence is 3 years) will be excluded from this measure.

Another condition provided by the Romanian law is that the judge compares the value of the property acquired lawfully by the accused 5 years before and, if necessary, after the moment of committing the offence. If the disproportion is obvious, manifest, it will be possible to order extended confiscation.

But the most important criterion in the option for the special measure is left to the magistrate. It is about his subjective appreciation of ordering or not the extended confiscation. The law speaks of "the conviction that the acquired goods come from criminal activities such as those listed above". We believe that the difference between "criminal activities" and "crimes" should be noted. And this because the person will only be tried and convicted for a "pretext-offence", as the activities that generated the goods that will be confiscated are not considered offences, as defined by the Criminal Code. So, we can observe that the extended confiscation can be ordered only subsequently to a criminal trial. The rules of criminal procedure should apply, excepting only the standard of proof.

15 Streteanu, F., Considerații privind confiscarea extinsă, Caiete de drept penal, nr. 2/2012, pp. 11-28 
It has been shown by the Romanian scholars that, in practice, the text of the law establishes here a legal presumption based on the following elements of the factual situation already proven: firstly, the perpetration of the offence (for which the conviction is ordered), secondly, the existence of goods that cannot be justified by the convict's legal income, thirdly, other factual elements which are demonstrated and can be shown to be relevant to the case. These clues lead to the Court's conviction (simple presumption), that the goods that cannot be justified have been obtained from criminal activities of the nature of the one(s) for which the conviction sentence is pronounced ${ }^{16}$.

In conclusion, in Romanian law, the extended confiscation is a "preventive" or "security measure", not a punishment. Also, it requests necessarily a conviction for a serious criminal offence, but the proceeds confiscated may be only related to that offence. The standard of proof is the "intimate conviction", but based also on presumptions and factual elements.

\section{REMOVING THE STATE OF DANGER OR PUNISHING THE OWNER? THE CONCEPT OF DANGEROUSNESS OF THINGS}

In general, safety measures are related with the concept of social defence and they were developed in Europe at the beginning of the last century, particularly during the years 1920-1930. Emanuele Carnevale ${ }^{17}$ defines the safety measure as "a means of defence, not a criminal one, as a result of an offence committed or only of a behaviour having the external characteristics of the offence and for which one takes into account subjectivity and the dangerousness characteristic of the agent, due to which the punishment cannot be applied or is unsuitable".

Extended confiscation, sometimes viewed as a distinct measure and other times as a type of special confiscation, the central object of our brief analysis, presents a number of specific elements that, on the one hand, assimilate it to the safety measures that we can call "classical" but on the other hand delimitate it considerably from them, bringing it closer to punishments.

First of all, we note that it has been said ${ }^{18}$ that extended confiscation was mistakenly qualified in Romanian system as a distinct safety measure, whereas in reality it is a modality, a variation of the special confiscation. It is further said that this

\footnotetext{
16 Nițu, D., Confiscarea extinsă. Confiscarea specială. Confiscarea de la terți, Caiete de drept penal, nr. $4 / 2017$

17 Carnevale, E., Rapport présenté au Congres penal et péniténciaire international de Berlin, 1935, în revista penală, an. III, nr. 3, Craiova, 1936, apud. M. Georgescu, op.cit., p. 40

18 Pașca, V., Drept penal. Partea Generală, Ed. Universul Juridic, București, 2015, p. 535
} 
interpretation also results from the provisions of Law no. 63/2012 (by which, as shown, the institution was adopted by Romania), according to which whenever reference is made to confiscation as a safety measure, it will also be considered to be made to extended confiscation. If the latter had been considered only a type of the former, this clarification of the law would no longer have been necessary.

In regard to the real difficulty of identifying the place of the measure among criminal law institutions, the Italian doctrine ${ }^{19}$ notes that its inclusion among safety measures is being challenged by some authors who consider it to be a sui generis sanction. The main argument in this respect we find the concept of the "dangerousness of things". We are dealing with a concept that is not to be understood as an attitude of a person to cause an offence. This is as an aptitude of a thing, if left in the sphere of a person, to constitute by itself an element of incitement, a provocation to commit in the future unlawful actions to the extent that the person would be certain that the proceeds of the crime would not be confiscated ${ }^{20}$.

In fact, the goods are not dangerous ${ }^{21}$, but the person holding them will be encouraged to commit unlawful acts. Therefore, could it not be said that it is rather the person that is "punished", under the assertion that an abstract state of danger is being prevented?

The Italian scholars define the situations as follows: confiscation refers to: the dangerousness of the thing by its nature, the dangerousness of the thing by reference to the offence, the dangerousness of the thing in relation to the person, the punishment of guilt-colpevolezza. ${ }^{22}$ The picture is complicated and blurred by three factors: the multi-faceted shape of prevention in and outside the system of criminal justice, the thin dividing line between prevention and repression, and the recent number of special provisions difficult ro reconciliate with the general framework ${ }^{23}$.

In German criminal system ${ }^{24}$, extended confiscation is neither a punishment nore a safety measure, it is a sui-generis „measure”. This specific criminal law institution

19 Fiandaca, G., Musco, E., Diritto penale. Parte generale, Settima edizione ristampa, Ed. Zanichelli, Bologna, 2018, p. 890

20 Massa, M., Confisca, Enc. Diritto, VIII, Milano , 1961, p. 983; ibid. Fiandaca; Musco, p. 890

21 In older cases in US, the rationale of forfeiture was that the property itself had done something wrong, see Cassella, op.cit, note 1, p. 18

22 Epidendio, T.E., La confisca nel diritto penale e nel sistema delle responsabilita degli enti, CEDAM, 2011, p. 69

23 Panzavolta, M.; Fluor, R., The Italian „non-criminal system” of asset forfeiture, in: Rui, Sieber, op. cit. note 1, p. 111

24 For a comparative study regarding confiscation in German Criminal law, see Rübenstahl, M, Der Umfang der Vermögensabschöpfung beim Unternehmen in Deutschland und Italien, in DPC, 2/2012, rivista 
is defined in Section 11 of the Criminal Code, as: „measure means the rehabilitation and incapacitation, confiscation, deprivation and destruction" 25 .

According to Section 73d of the Criminal Code (St.GB), extended confscation is to be ordered if the circumstances justify the assumption that the objects were aquired as a result of an unlawful act. This has been interpreted as requiring the judge to be convinced having considered all the evidence of the illicit origin of the assets in question ${ }^{26}$.The German Federal Supreme Court (Bundesgerichtshof) concluded that the extended confiscation is compatible with German Constitution so that the trial judge has to be „completely convinced” of the ilicit origin of the assets. ${ }^{27}$ In Germany, the extended confiscation is always connected to the conviction of a person (similar in Romania and Italy) or at least to the declaration of an unlawfull act that has been committed. It is not the property itself that is the focus of the proceedings, it is the person ${ }^{28}$.

Considering that it applies to other assets than those which are subject to confiscation under ordinary law (improperly called, we believe, special ${ }^{29}$ ), extended confiscation refers in a more abstract way to the dangerousness of things. This is because, while some of them are subject to confiscation from the point of view of the danger they denote themselves (such as drugs, weapons, counterfeit money or explosives), extended confiscation refers to other goods, that are not dangerous. An expensive car, a real estate or gold are not dangerous. From this perspective, this measure concerns a person more than its possessions. So, we believe that the essence of criminal personal punishment is more pronounced, and the inclusion of extended confiscation in some criminal systems among "security measures" is just a purely formalistic deception.

trimestriale, on [http://dpc-rivista-trimestrale.criminaljusticenetwork.eu/pdf/DPC_Trim_2_201210-39.pdf] Accessed 03.03.2019

25 German criminal code, accesed on [https://ec.europa.eu/anti-trafficking/sites/antitrafficking/files/ criminal_code_germany_en_1.pdf] Accessed 02.04.2019

26 Decision 2 BvR 564/95, 14.01.2004, par. 92, German Constitutional Court, in J. Boucht, The limits of asset confiscation. On the legitimacy of extended appropriation of criminal proceeds, Hart Publishing, Oxford and Portland, Oregon, 2017, p. 187

27 The German Court held that: „the order of extended confiscation id considered only if the judge, on the basis of exhaustive consideration of all the evidence is fully convinced that the defendant has obtained the objects covered by the order from unlawful acts, without the latter having to be ascertained in detail", J. Boucht, op.cit. note 26, p. 190

28 Esser, R., A civil Asset Recovery Model. The German Perspective and European Human Rights, in Rui, Sieber, op. cit. note 1, p. 74

29 For critiques related to the use of the term "special confiscation", also see M. Georgescu, op.cit., p. 192. The author states that the measure called "general" entrusted the State or the sovereign with all property belonging to the convict in the case of serious crimes punishable by capital punishment committed against the sovereignity or the State 
Is "the state of danger" to which the general rule of art. 107 par. 2 of the Romanian Criminal Code refers a state of a good or a dangerousness of a person? The answer is difficult and so, depending on the arguments that lean towards one solution or another, the placement of the special confiscation in general, and of the extended one in particular, closer to the punishments or the security measures.

The option of European continental criminal policy, which has concentrated and systematized security measures, is a tributary to the Italian criminal law of the time, notably to the 1930 "Rocco" Criminal Code. The notion of "dangerousness" has gradually emerged as a new area of criminal law intervention ${ }^{30}$, and a series of new terms will be associated, such as "dangerous delinquent", "moral hazard, "social defence", "safety measures", "state of danger", "harm".

There have even been mentions of a "culture of danger" 31 , by bringing the personality of the offender into the center of the criminal process and penitentiary science, putting the offence at a secondary level. Tradition punishment has been supplemented by a "second track" of legal consequences for criminal conduct, which are based exclusively on harm prevention principle, that is to say on the dangerousness of the defendant regardless of his personal culpability ${ }^{32}$.

The criminal action would therefore be determined by a series of "extra penal" concepts that contribute to the shaping of a personality of the offender as a fundamental element of the criminal process. The dangerousness is, therefore, concludes Filippo Gramatica in $1933^{33}$, "a state of the offender characterized by the more or less likely tendency to commit crimes".

Therefore, if, on the one hand, we are talking about a social danger of crimes, there are certain states of danger that concern the person of the offender, falling into what is called "subjective dangerousness". Others refer to goods in connection with the act committed by the offender (objective dangerousness) ${ }^{34}$. The fact that

30 Doboș, C., Intre a preveni şi a pedepsi: un nou tip de acţiune penală în România interbelică, în Studia Politica:Romanian Political Science Review, 13(3), 477-497, accesat la [http://nbn-resolving.de/urn:nbn:de:0168-ssoar-447444].

31 Michel Foucault stated that "the motto of liberalism is to live dangerously (...) in the sense that individuals are constantly put in danger or, in fact, are conditioned to perceive their situation, life, present and future as generating danger" (M. Foucault, Nașterea biopoliticii, Cursuri ținute la College de France, Ed. Ideea Design \& Print, Cluj, 2007, pp. 69-70; C. Doboș, ibid. p. 478)

32 Vogel, J., The Legal Construction That Property Can Do harm. Reflections on the Rationality and Legitimacy of Civil Forfeiture, in Rui, Sieber, op. cit. note 1, p. 232

33 Gramatica, F.,Principii de drept penal subiectiv (tradus de J. Moruzzi), Ed. Universul, București, 1934, p. 161

34 Niculeanu, C., Regimul juridic al confiscării speciale în lumina noului cod penal, în Dreptul, nr. 6/2013, p. 146 
a medical safety measure (e.g., medical hospitalization for mental illness) has the purpose of removing the state of danger for the society represented by the person does not leave any doubt. The arguments that there might be a punishment of the person are totally unsupported, even if safety measure facilities are sometimes assimilated to places of detention. The curative element is here decisive.

The legal responsibility that involves the implementation of the safety measures in general can only be, it has been said, an objective responsibility. Unlike the subjective criminal liability, which is predominantly retributive, it has an exclusively preventive character. ${ }^{35}$ Medical safety measures are definitely criminal sanctions because they are the consequence of breaching the precept of the criminal text, they are coercive measures because they obviously involve a restriction and even a deprivation of the person's freedom and are applied by the judicial authorities. Even if we were to accept, for the sake of argument, the contrary view regarding medical safety measures, the mechanism of criminal liability for other categories of security measures cannot be explained otherwise, the criminal liability being unequivocally an objective one ${ }^{36}$.

In the case of extended confiscation, the property do not per se pose a state of danger. It is not directly related to the offence that caused the conviction of the accused, getting far from the classical system of responsibility that governs the safety measures. Then what kind of state of danger, more precisely whose state of danger are we talking about? As stated in the doctrine, if this state of danger were absent, the inclusion of the institution in the safety measures would be questioned ${ }^{37}$.

\section{SOME PUNISHMENT ELEMENTS REGARDING EXTENDED CONFISCATION IN ROMANIAN LAW}

The first element distinguishing extended confiscation from other safety measures, which has led to it also being called improper "non-conviction criminal confiscation" is that the proceeds to which it refers do not come from an offence the person has been convicted for. Nevertheless, the "occasion" of extended confiscation, its pretext, is the criminal trial and the conviction for another offence. Indeed, a conviction does exist, but only one pronounced for other offence than the one the goods subject to extended confiscation were obtained from.

\footnotetext{
35 Paşca, V., Măsurile de siguranţă-sancţiuni penale, Ed. Lumina Lex, Bucureşti, 1998, p.23

36 Stănilă, L.M., Răspunderea penală obiectivă şi formele sale în dreptul penal român, în Analele Universității de Vest Timișoara, Seria Drept, nr. 2/2011, p. 94, accesat la [https://drept.uvt.ro/administrare/ files/1481042436-laura-maria-stanila--.pdf] Accessed 03.04.2019.

37 Ciopec, F., Confiscarea extinsă, între de ce și cât de mult, Ed. CH Beck, București, 2015, p. 109
} 
In the context of the extension and diversification of the individualisation of the punishments (also by restorative justice), it can be stated that the current Romanian system will exclude extended confiscation when it comes to a minor offender against whom an educational measure has been applied. The decision to postpone the punishment is the same (the person is guilty, but it he is not called formally a "convict"). Therefore, it will only be the case of conviction (called sometimes a stricto sensu conviction) under detention regime or with conditional suspension (Article 91 of the Criminal Code).

So, the severity of the related conviction appears to be higher (on the one hand, by failing to fulfill the negative conditions provided by Article 81 and Article 83 of the Criminal Code-which do not lead to a "conviction", and on the other by the listing in Article 112 of crimes of increased gravity).

The Italian scholars noticed the mechanism of practical compensation for the incomplete support of a criminal charge, materialized, not without truth, in the expression "poca prova, poca pena" (little evidence, little punishment) ${ }^{38}$. This means in the criminal proceedings that, given the assertions in defence of the accused, the judge was not entirely convinced that the evidence did indeed prove the defendant's guilt, but did not have the courage to absolve him, and convicted him to a not so severe punishment. If the court has doubts about guilt, it should argue that the defendant is innocent and not apply a reduced sentence in a compensatory spirit. Similarly, regarding extended confiscation, the judge, sometimes noticing that the evidence does not fully support the "pure conviction" solution, which would also involve taking the extended confiscation, could choose one of the innovations of the Romanian Criminal Code not found among the strict conviction sentences.

It is obvious that the measure concerns goods against which no conviction sentence has been pronounced and will not be pronounced in the future ${ }^{39}$. The criminal court has not been called to judge the alleged activities the goods subject to extended confiscation come from. In regard to these facts, there will obviously not exist a complete analysis of the typicality (condition of a behaviour to consist an offence), as is necessary to be done with respect to the pretext-offence of the measure.

However, can a person be definitively deprived of some of their property (by means of a measure called in the old doctrine of an "eliminatory" type), things

\footnotetext{
38 Masera, L., "Poca prova, poca pena: una curiosa decisione della cassazione sulla rilevanza dell'atipicità del decorso causale al fine del riconoscimento delle circostanze attenuanti generiche", disponibil la [https://www.penalecontemporaneo.it/d/6150-poca-prova-poca-pena-una-curiosa-decisione-della-cassazione-sulla-rilevanza-dell-atipicita-del-deco] Accesssed 21.02.2019

39 Ciopec, op. cit. note 37 , p. 138
} 
which have not been found in a conviction sentence to be the lato sensu product of a crime, without talking of a punitive measure? Or only affirming the confiscation regards prevention is because it is considered more "noble" than repression ${ }^{40}$ ?

Some scholars stated ${ }^{41}$ that taking into account, in particular, the provisions of the fundamental law, the regulation of "extended confiscation" as having the nature of a safety measure is an "impossible mission". Moreover, other authors ${ }^{42}$ state that the measure does not present the features of a safety measure, especially concerning its preventive nature, as its strong repressive nature brings it closer rather to the specificity of complementary punishments.

Even the above-mentioned European Framework Decision, when providing the definition of "confiscation", admits that it may also be a punishment or other type of measure, stating in art. 1: "confiscation" means a punishment or a measure ordered by a court following a proceeding in connection with an offence or offences, resulting in the definitive dispossessing of the property.

Directive 2014/42/EU no longer refers to "punishment", providing in paragraph 13 that: "Freezing and confiscation under this Directive are autonomous concepts which should not prevent Member States from implementing this Directive by means of instruments which under national law would be considered as punishments or other types of measures". Apparently, the new Directive understood the danger of assimilation of the measure to a punishment, giving the Member States the freedom to choose in this respect, without however naming the type of punishment applied, making room for a new concept, quite frequently mentioned in the recent doctrine, of sui generis punishment.

In considering this terminology, some scholars said that it is a punishment in the European sense ${ }^{43}$. German legislation, as we observed above, treats the extended confiscation as a particular criminal law measure, not a safety measure, nor a punishment. We can remark that this can be the right position in understanding the European regulations and concepts.

The view of some concepts of undefined nature in the case law of the Strasbourg Court is still to be found in the case of the more famous concept of "criminal ac-

40 Panzavolta; Flor, op. cit. note 23, p. 111

41 Hotca, M.A., Din nou despre confiscarea extinsa. Necesitatea reconsiderarii reglementarii. Solutii propuse, accessed at [https://www.juridice.ro/200465/din-nou-despre-confiscarea-extinsa-necesitatea-reconsiderarii-reglementarii-solutii-propuse.html] Accessed 23.03.2019

42 Gorunescu, M., în Colectiv, Noul Cod penal comentat. Partea generală, Ed. a III-a revăzută și adăugită, Ed. Universul Juridic, București, 2016, p. 662

43 Udroiu, M., Drept penal. Partea generală, Ed. IV, Ed. CH Beck, București, 2017, p. 488 
cusation in the European sense". This reminds us of the criteria laid down in the jurisprudence of Engel versus The Netherlands. ${ }^{44}$ However, even if the institution is present in Romanian law as a result of the transposing of Community instruments, we believe that the real challenge is to find the place of it among criminal law instruments in relation to domestic law.

But even in the context of the intense internationalization and europeanization of criminal law in the matter of identifying, freezing and confiscating the proceeds of crime, we cannot omit the fact that the national legal systems differ in many ways. Sometimes uniformity is in contradiction with a series of constitutional principles which cannot be derogated from.

Extended confiscation obviously concerns more the person than the property. It "punishes" the offender for holding things of an uncertain source, allegedly criminal, but still without having convicted him for a predicate-crime. It has been asserted ${ }^{45}$ with good reason that we should accept that leaving alleged proceeds of criminal activity in the civil circuit is not necessarily a problem for society and does not per se create a state of danger. But is it moral?

Are we therefore talking about a danger of the person who possesses them, or simply not even that, as it is about punishing the person for an unjustified wealth, corroborated with a conviction for a related offence? The idea of prevention fades and the notion of "dangerousness", used by the old doctrine, seems to be the key: the person has the tendency to commit new crimes, presumed to originate from the possession of goods, which the state will confiscate. Thus, we believe, we are dealing with prevention by punishment, and not pure prevention (punitur ut ne peccetur).

Some scholars also point out that "it is known that, in the case under discussion, the stone was thrown again by the European Court of Human Rights, starting with the judgment of Sud Fondi vs Italy ${ }^{46}$, thus confirming the finding of "the nature of punishment according to art. 7 of the Convention". On this basis, the Court has clarified as a sine qua non condition for ordering urban confiscation ${ }^{47}$ as well as any other type of confiscation and the character of "intrinsically punitive

44 The Engel criteria, used also to qualify if a measure should be qualified as a criminal measure, are (1) the clasification of the measure in criminal law, (2) the nature of the offence, and (3) the degree of severity of the penalty risked. (see also Welch v. The United Kingdom, app. nr. 17440, para.32)

45 Ciopec, op. cit. note 37, p. 110

46 Application 75909/01, Decision of 20 January 2009

47 By means of "Confisca urbanistica", a measure stipulated in the Italian criminal law: "the final sentence of the criminal judge establishing the existence of illegal land plotting provides for the confiscation of the land and of the abusively constructed works." 
sanction" of it - finding an intellectual connection (consciousness and will) that allows the detection of an element of responsibility in the offender's behaviour". ${ }^{48}$

Even the ECtHR is oscillating ${ }^{49}$. In Walsh vs $U K^{50}$ the Court faced the question of whether confiscation civil proceedings were criminal in nature. The Court held that "there was no finding of guilt of specific offences. The recovery order was not punitive in nature, the amount of money involved is not itself determinative of the criminal nature of the proceedings". In Butler vs. UK ${ }^{51}$, the Court regarded a forfeiture order as a preventive measure, which can not be compared to a criminal sanction, since it was designed to take out money that was presumed to be tied with trade with drugs. In Geerings vs. The Nederlands ${ }^{2}$, ECtHR took a different approach, holding that "if it is not found beyond a reasonable doubt that the person affected had committed the crime and if cannot be established as fact that any advantage, illegal or otherwise, was actually obtained, such a measure can only be based on a presumption of guilt".

In a recent decision, in Telbis and Viziteu vs. Romania $a^{53}$, Court held that "the confiscation had been part of a fight against corruption, which was a legitimate aim for the Government to pursue. There were also common European legal standards which encouraged the seizure of property linked to such serious crimes, even without a prior conviction". So, ECtHR in recent jurisprudence accepts that the Romanian type of extended confiscation is part of criminal policy to fight against corruption (the case refered to the extended confiscation of goods detained by the wife and daughter of a doctor convicted for taking a large number of bribes).

\section{PROPOSED MODIFICATION OF ROMANIAN CRIMINAL CODE WITH REGARD TO EXTENDED CONFISCATION. A HIGHER STANDARD OF PROOF?}

According to Law sent in September 2018 for promulgation ${ }^{54}$, with respect to which, in the Decision no. 650 dated 25 October $2018^{55}$, the Romanian Consti-

\footnotetext{
48 Mannes, V., „La confisca senza condanna al crocevia tra Roma e Strasburgo: il nodo della presunzione di innocenza", accesat la[ https://www.penalecontemporaneo.it/upload/1428820687MANES_2015.pdf] Accessed 02.03.2019

49 Esser, op. cit. note 28, pp. 93-94

50 Application no. 43384/05, Decision of 21 November 2006

51 Application no. 41661/98, Decision of 27 June 2002

52 Application no. 30810/03, Decision of 1 March 2007

53 Application no. 47911/15, Decision of 26 June 2018

54 accessed at [http://www.cdep.ro/pls/proiecte/upl_pck2015.proiect?idp=17241]

55 Published in the Official Journal no. 97, 7 February 2019
} 
tutional Court admitted a series of criticisms, the main objective of the amendments to the safety measure under analysis was to harmonize the legislation with Directive 2014/42/EU. However, it appears from the Court's explanation that the legislator only formally stated this objective, with some modifying provisions being manifestly contrary to the European text.

The law (which at this moment is in new parliamentary procedures, after the Court decision) does not change the nature of the extended confiscation, maintaining it between the safety (or preventive) measures.

As far as we can see, on the one hand, intention of the legislator was to change the current list of crimes that permit the extended confiscation to be ordered, and on the other hand, the standard of proof needed to order the measure is amended - from simple conviction (which is more than what Directive 2014/42/EU required) to conviction beyond any doubt (excluding even the reasonable doubt $)^{56}$. In a very interesting movement, for moment stopped by the Court, the legislator tries to introduce a criminal procedure standard of proof, where the standard is in fact one of balance of probabilities, even it Romanian legislation calls it "conviction".

The law provided that:

"In Article 1121, paragraphs (1) and (2) shall be amended and shall have the following content:

"Article 1121. (1) Goods, other than those provided for in art. 112, shall also be subject to confiscation, when a person is convicted of a crime susceptible of generating a material benefit for them, and for which the punishment provided by the law is 4 years or more of imprisonment, and the court forms its conviction, based on the circumstances of the case, including the factual elements and the evidence presented, that the respective goods come from criminal activities. The conviction of the court can also be based on the disproportion between the person's legal income and wealth.

(2) Extended confiscation is ordered if the following conditions are met cumulatively: (a) the value of the property acquired by the convicted person over a period of 5 years before and, where appropriate, after the offence has been committed, up to the date of the issue of the court notification, manifestly exceeds the wealth ob-

56 Lord Denning defined the reasonable doubt so: "There is no need to achieve certainty, but a high level of probability must be attained. The standard beyond any reasonable doubt does not signify the proof beyond any shadow of doubt. The law does not protect society if it admits that imaginary possibilities can divert the course of justice. If the allegation is proven so that no distant probability is found in its favor, which would correspond to the argument - of course it is possible, but it is not at all probable then the allegation is proven beyond reasonably doubt" 
tained by the person legally; b) the evidence shows that the goods come from criminal activities of the nature provided in par. (1)".

In Article $112^{1}$, after paragraph (2), a new paragraph will be inserted, paragraph $\left(2^{1}\right)$, which reads as follows: "( $\left.2^{1}\right)$ The court's decision must be based on clear evidence, beyond any doubt, that the convicted person is involved in criminal activities producing goods and money".

In Article $112^{1}$, paragraph (3) shall be amended and shall have the following content: "(3) For the application of the provisions of para. (2) account shall also be taken of the value of the assets transferred by the convicted person or a third party to a member of the family, if the person knew that the purpose of the transfer was to avoid confiscation or to a legal entity over which the convicted person holds control. Confiscation will be ordered within the bounds of the transferred assets when the illicit transfer can be proven by clear evidence beyond any doubt."

By means of the aforementioned decision, the Constitutional Court declared unconstitutional the phrase "from the evidence produced", the phrase "clear evidence, beyond any doubt" and the phrase "if the person knew that the purpose ..."

Even in a simple reading, the standard of proof necessary for ordering the extended confiscation laid down by Directive 2014/42/EU is no longer even of a conviction, but more reduced, while the attempt by the Romanian authorities to impose a higher standard seems to be unrealistic. Recital 21 of the Directive provides that:

"Extended confiscation should be possible where a court is satisfied that the property in question is derived from criminal conduct. This does not mean that it must be established that the property in question is derived from criminal conduct. Member States may provide that it could, for example, be sufficient for the court to consider on the balance of probabilities, or to reasonably presume that it is substantially more probable, that the property in question has been obtained from criminal conduct than from other activities. In this context, the court has to consider the specific circumstances of the case, including the facts and available evidence based on which a decision on extended confiscation could be issued. The fact that the property of the person is disproportionate to his lawful income could be among those facts giving rise to a conclusion of the court that the property derives from criminal conduct. Member States could also determine a requirement for a certain period of time during which the property could be deemed to have originated from criminal conduct." 
The Constitutional Court has rightly observed that the law regarding the changes of extended confiscation contains a series of confusions and inaccuracies which, if adopted, would divert the purpose of the measure from its rationale.

The Court finds that "the legislator has acted with the notion of evidence for the court to base its judgment applying the extended confiscation security measure on "clear evidence, beyond any doubt". It follows that the court must have separate evidence to be able to order said measure; thus, by producing such evidence, it is enough to prove the criminal act itself, a hypothesis in which the special confiscation, rather than the extended one, would be applied.

Thus, the use of the phrase "beyond any doubt" in art. $112^{1}$ par. $\left(2^{1}\right)$ and (3) of the Criminal Code makes it unnecessary to regulate the institution of extended confiscation. This is because it establishes a standard of proof that requires the full settlement of the criminal legal relationship of conflict, with the consequence of the applicability of the special confiscation institution and the establishment of a more severe condition than those provided for in Directive 2014/42/EU on evidence regime."

In confirming the „civil” standard of proof, in recent precited Telbis and Viziteu vs. Romania, ECtHR stated that ,it was legitimate for the relevant domestic authorities to issue confiscation orders on the basis of a preponderance of evidence suggesting that the respondents' lawful incomes could not have sufficed for them to acquire the property in question. Indeed, whenever a confiscation order was the result of proceedings related to the proceeds of crime derived from serious offences, the Court has not required proof „beyond reasonable doubt” of the illicit origins of the property in such proceedings. Instead, proof on a balance of probabilities or a high probability of illicit origins, combined with the inability of the owner to prove the contrary, have been found to suffice for the purposes of the proportionality test under Article 1 of Protocol No. 1. The domestic authorities were given leeway under the Convention to apply confiscation measures not only to persons directly accused of offences, but also to their family members and other close relatives who had been presumed to possess and manage the "ill-gotten" property informally on behalf of the suspected offenders, or who otherwise lacked the necessary bona fide status".

We can observe that the legislator has not fully understood the modern standards of proof and the relationship between the concept of proof and that of "factual element". The last is being sufficient, according to European standards, to establish the illicit origin of goods subject to extended confiscation ${ }^{57}$. Romanian extended confis-

57 Criste L., Appraisal of evidence and the standard of proof in the common procedure and in the proceeding of plea argument, from a comparative law perspective, in Criminal Law Writings nr. 4/2018, Ed. Universul 
cation, being a criminal-confiscation, but also only a "related to an offence" measure, does not need a standard of proof similar to the one needed for a criminal conviction.

So, the law project seems to have aimed to operate with a double standard of proof. Firstly it admitted the sufficiency of existence of factual elements as well in forming the judge's conviction (and the evidence is, broadly speaking, a factual element, but here notions have different meanings). However, next it speaks only of evidence in proving the source of the goods subject to the measure.

Moreover, using the phrase "clear evidence", has in our opinion the role of raising the standard of proof, given the fact that in procedural sense, the antinomy clear/ unclear evidence does not exist, although it is sometimes used in the jurisprudence. The evidence exists or not, it is lawful or illegally obtained; only the court's conviction may be certain or less certain. The role of regulation seems to be to avoid abusive confiscations, while introducing hybrid concepts foreign to the Romanian system.

The new system proposed by the Romanian legislator and declared contrary to the Constitution aimed to reach a compromise between the continental standard of the judge's conviction and the common-law one, also present in Romanian procedural system after 1 February 2014 (when the new code was enforced).

Intimate conviction, the current and traditional standard in continental systems, it is said, does not mean arbitrariness but is formed in relation to the evidence debated and produced under the conditions of the contradiction principle, and it is also necessary to present the reasons that led to their evaluation in a certain way or to their removal. It has been said in relation to the notion that the term intimate indicates something personal or individual, and conviction, a firm, certain opinion, which is required in an obvious manner ${ }^{58}$.

The text also refers to the notion of "beyond any doubt", which seems, in part, to refer us to the "beyond any reasonable doubt" standard. Since the classical standard of this kind admits the existence of a doubt in establishing the guilt, but it must lie within reasonable limits, the standard of the new provision, as it excludes the reasonableness of a doubt, is similar to that of pure certainty ${ }^{59}$. The legislator therefore proposed, in the matter of extended confiscation, a higher standard of proof than that required for a conviction, which is absolutely atypical.

Juridic, București, pp. 80-85

58 Mateuț, Gh., Libertatea aprecierii probelor, în Revista română de drept penal, nr. 3, 2004, p. 44

59 Also see Hotca, M.A., Neconstitutionalitatea si inutilitatea dispozitiilor care reglementează confiscarea extinsă, accessed at [https://www.juridice.ro/199507/neconstitutionalitatea-si-inutilitatea-dispozitiilor-care-reglementeaza-confiscarea-extinsa.html] Accessed 03.03.2019 
We can conclude, regarding the recent events in Romanian system that this attitude of the legislator was rightly censored by the Romanian Constitutional Court. The Court repeats that there is not always a need to establish a direct link between the assets and the alleged crime, since it is also possible to confiscate property that is disproportionate with the individual's income, and whose provenance the individual can not justify. The solution in Romanian system may be, in our opinion, moving the extended confiscation from a preventive to a sui-generis criminal measure.

\section{FINAL CONCLUSIONS}

It is certain that the extended confiscation is a compromise, which states have to accept, being faced with the diversification of the ways of obtaining high benefits from organized crime. Even it is qualified as a "civil forfeiture", like in American system, a "confiscation order", like in German law, or a "preventive/security measure", like in Italian or Romanian criminal system, if some distinctions are not taken as point of departure, negative effects will follow.

The Constitutional Court of Romania has so far protected this sanction from criticism, some not without support, related to the issue of sanctioning a person for possessing goods of questionable origin without a direct conviction, but only in the presence of a related offence.

Whether we see it as a variety of special confiscation, as a real punishment, lost among the "classic" preventive measures, or as a new, sui-generis European measure, extended confiscation is an institution that is developing under our eyes.

The repressive characteristics will be following it for a long time, and the context of the fight against profit-driven organized crime attempts to counterbalance this. The way in which European criminal law systems will receive extended confiscation depends on how the specificity of each state faces the community regulations, and it is a real challenge in the near future.

\section{REFERENCES}

\section{BOOKS AND ARTICLES}

1. Boucht, J., The limits of asset confiscation. On the legitimacy of extended appropriation of criminal proceeds, Hart Publishing, Oxford and Portland, Oregon, 2017

2. Carnevale, E., Rapport présenté au Congres penal et péniténciaire international de Berlin, 1935, în revista penală, an. III, nr. 3, Craiova, 1936

3. Ciopec, F., Confiscarea extinsă, între de ce și cât de mult, Ed. CH Beck, București, 2015, p. 109 
4. Colectiv, Noul Cod penal comentat. Partea generală, Ed. a III-a revăzută și adăugită, Ed. Universul Juridic, București, 2016, p. 662

5. Constantin, V., Drept internațional public, Ed. Universității de Vest, Timișoara, 2004, p. 32

6. Corvi, P., La confisca nei reati di criminalita organizzata, in Sequestro e confisca, a cura di Mariangela Montagna, G.Giappichelli Editore-Torino, 2017, p. 432

7. Criste L., Appraisal of evidence and the standard of proof in the common procedure and in the proceeding of plea argument, from a comparative law perspective, in Criminal Law Writings nr. 4/2018, Ed. Universul Juridic, București, pp. 80-85

8. Epidendio, T.E., La confisca nel diritto penale e nel sistema delle responsabilita degli enti, CEDAM, 2011, p. 69

9. Fiandaca, G., Musco, E., Diritto penale. Parte generale, Settima edizione ristampa, Ed. Zanichelli, Bologna, 2018, p. 890

10. Furcinitti, G., Frustagli, D., Il sequestro e la confisca dei patrimoni illeciti nell'Unione Europea, Wolters Kluwer, CEDAM, 2016, pp. 10-11

11. Gramatica, F., Principii de drept penal subiectiv (tradus de J. Moruzzi), Ed. Universul, București, 1934, p. 161

12. Ionescu-Dolj, I, în G. Constantin Rătescu, Asnavorian, H., Pop, T., Dongoroz, V., Codulpenal "Regele Carol II" adnotat, vol. I-III, Editura Socec \& Co S.A.R., Bucureşti, 1937, p. 169

13. Massa, M., Confisca, Enc. Diritto, VIII, Milano, 1961, p. 983

14. Mateuț, Gh., Libertatea aprecierii probelor, în Revista română de drept penal, nr. 3, 2004, p. 44

15. Niculeanu, C., Regimul juridic al confiscării speciale în lumina noului cod penal, în Dreptul, nr. 6/2013, p. 14

16. Nițu, D., Confiscarea extinsă. Confiscarea specială. Confiscarea de la terți, Caiete de drept penal, nr. 4/2017

17. Pașca, V., Drept penal. Partea Generală, Ed. Universul Juridic, București, 2015, p. 535

18. Paşca, V., Măsurile de siguranţă - sancţiuni penale, Ed. Lumina Lex, Bucureşti, 1998, p.23

19. Pradel, J., Droit pénal comparé, 4 édition, Dalloz, Paris, 2016, pp. 598-599

20. Rui, J.P., Sieber, U. (editors), Non-conviction based confiscation in Europe. Possibilities and limitations on rules enabling confiscation without a criminal conviction, Duncker and Humblot, Berlin, 2015

21. Streteanu, F., Considerații privind confiscarea extinsă, Caiete de drept penal, nr. 2/2012, pp. $11-28$

22. Udroiu, M., Drept penal. Partea generală, Ed. IV, Ed. CH Beck, București, 2017, p. 488

\section{EU LAW}

1. Directive 2014/42/EU, Official Journal of the European Union no. L94/65, 28 March 2014

2. Framework Decision no. 2005/212/JAI on the confiscation of crime-related products, instrumentalities and other property, published in the Special Edition of the Official Journal of the European Union no. 0, 1 January 2007 


\section{ECtHR}

1. Gogitidze and others vs. Georgia, Application 36862/05, Decision of 12 May 2015

2. Sud Fondi vs Italy, Application 75909/01, Decision of 20 January 2009

3. Walsh vs UK Application no. 43384/05, Decision of 21 November 2006

4. Butler vs UK Application no. 41661/98, Decision of 27 June 2002

5. Geerings vs. The Nederlands Application no. 30810/03, Decision of 1 March 2007

6. Telbis and Viziteu vs. Romania Application no. 47911/15, Decision of 26 June 2018

\section{WEBSITE REFERENCES}

1. Doboș, C., Între a preveni şi a pedepsi: un nou tip de acţiune penală în România interbelică, în Studia Politica:Romanian Political Science Review, 13(3), 477-497, la [http://nbn-resolving. de/urn:nbn:de:0168-ssoar-447444] Accesed 25.02.2019

2. Franssen, V., The EU's Fight Against Corporate Financial Crime: State of Affairs and Future Potential, at [https://static1.squarespace.com/static/56330ad3e4b0733dcc0c8495/t/5bb1700 2f4e1fcbd8b2b47c2/1538355202984/Vol_19_No_05_Franssen.pdf] Accesed 25.02.2019

3. Hotca, M.A., Neconstitutionalitatea si inutilitatea dispozitiilor care reglementează confiscarea extinsă, at [https://www.juridice.ro/199507/neconstitutionalitatea-si-inutilitatea-dispozitiilor-care-reglementeaza-confiscarea-extinsa.html] Accesed 25.02.2019

4. Hotca, M.A., Din nou despre confiscarea extinsa. Necesitatea reconsiderarii reglementarii. Solutii propuse, at [https://www.juridice.ro/200465/din-nou-despre-confiscarea-extinsa-necesitatea-reconsiderarii-reglementarii-solutii-propuse.html] Accessed 25.02.2019

5. Masera, L., „Poca prova, poca pena: una curiosa decisione della cassazione sulla rilevanza dell'atipicità del decorso causale al fine del riconoscimento delle circostanze attenuanti generiche", disponible at [https://www.penalecontemporaneo.it/d/6150-poca-prova-poca-pena-una-curiosa-decisione-della-cassazione-sulla-rilevanza-dell-atipicita-del-deco] Accesed 25.02.2019

6. Mannes, V., „La confisca senza condanna al crocevia tra Roma e Strasburgo: il nodo della presunzione di innocenza", accesat la [https://www.penalecontemporaneo.it/upload/1428820687MANES_2015.pdf] Accesed 25.02.2019

7. Rübenstahl, M, „Der Umfang der Vermögensabschöpfung beim Unternehmen in Deutschland und Italien", in DPC, 2/2012, Rivista trimestriale, on [http://dpc-rivista-trimestrale.criminaljusticenetwork.eu/pdf/DPC_Trim_2_2012-10-39.pdf] Accesed 25.02.2019

8. Sigursteinsson, B. H. „The Globalization of Crime Control: The Use of Non-criminal Justice Responses for Countering Organized Crime", p. 2, at [https://www.mobt3ath.com/uplode/ book/book-48543.pdf] Accessed 12.03.2019

9. Stănilă, L.M., Răspunderea penală obiectivă şi formele sale în dreptul penal român, în Analele Universității de Vest Timişoara, Seria Drept, nr. 2/2011, p. 94, accesat la [https://drept.uvt.ro/ administrare/files/1481042436-laura-maria-stanila--.pdf] Accesed 21.01.2019 